\title{
6. Reporting sustainability in the English-language press of Southeast Asia
}

\section{ABSTRACT}

This article reports on a preliminary scan of six English-language newspapers in Southeast Asia, with a side comparison to a leading Australian newspaper, regarding their coverage of environmental sustainability issues over a two month period in 2005. It identifies the ownership and key politico-economic issues for each masthead, and does a detailed quantitative analysis of their subject matter and use of sources, followed by two case studies of complex, multisourced stories critical of corporate or government activities. The analysis draws on field theory, and canvasses debates about the power relations among journalists and sources. It concludes that there is a common set of journalistic practices across the sample regardless of national and political differences, but considerable diversity of approaches within that commonality. Patterns of ownership, particularly state vs non-state offer little general explanatory power for this diversity. Protection of the environment had 'motherhood status' in the reporting, but precisely because of this status no assumptions can be made about the quality of the coverage.

\section{CHRIS NASH and WENDY BACON}

University of Technology, Sydney

7 HE RESEARCH on which this article draws is a preliminary reconnaissance of the terrain on which journalists in Southeast Asia operate

when reporting on environmental sustainability issues (ESI). It covers a sample of the English-language press, which of course is a limitation given the range of different national languages used in the region, let alone subnational and trans-national languages and dialects within which journalists 
write and speak. In some countries, eg the Philippines, Malaysia and Hong Kong, English is a language spoken or read by a significant section of the national population; in others, eg Vietnam and Thailand, it is used by a relatively small number of people.

However, in all of the countries the English language media is read by most foreign diplomatic and business workforces, by many non-government organization (NGO) workers, and by some foreign tourists and travellers. It thus constitutes a major venue or field where the decisions, attitudes and activities of all who participate and contest the use of power in national decision-making are represented to the international stakeholders in foreign governments, transnational corporations and international NGOs (they themselves are often major forces setting the context for national players). While the study is restricted to the print medium, that is the form of journalism that is most easily circulated to international audiences in government and corporate bureaucracies for consideration and analysis. Each of the newspapers is based in a large metropolitan city, often the national capital, in countries where the bulk of the population resides elsewhere. This facilitates the ability of the major institutional players in the national arena to participate in the contest over the form and content of representation of issues relevant to them. However, it also reduces the relative capacity of non-metropolitan readerships and stakeholders to represent their own interests, especially if they conflict with those of metropolitan players.

All of the mastheads are highly regarded as serious newspapers, operate in multi-outlet markets, are internationally available in the region and on the internet, and share a common language. They would be aware of each others' relative standing and performance as a vehicle for the international representation of their national societies and the important news and issues of the day therein. For our purposes, their performance can also be interpreted as an indicator of the role and power of the journalistic media with respect to the poles of political, economic and social power in their respective constituencies, which is our particular interest.

\section{Theoretical framework}

The point of our larger study (which we introduce here) is to investigate the relationship between the exercise of power in the ideological (or symbolic) field of the media with relationships of power in the economic, military and 
political spheres. This categorisation of power draws on the IEMP taxonomy of Michael Mann (Mann, 1986, pp. 1-33). It is useful for us because we follow Schlesinger (1990) in wanting to decentralise the media into a set of relations with other sources of social power to see how its exercise of power might intersect with theirs, while at the same time recognising the distinctive specificities of each field of social relations. The political role of the military or coercive sphere is more or less significant, albeit for internal or external purposes, in most South-East Asian countries, and we agree with Mann that it needs to be recognized both as a source of social power in its own right as well as for its distinctive interactions with the political and economic fields. Therefore, while we agree with Schlesinger (1990, p. 77) in valuing Bourdieu's relational approach to the analysis of relations within fields of social power (Bourdieu \& Waquant, 1992, pp. 94-115), we suggest that Mann's institutional taxonomy is a refinement of Bourdieu's categories of economic, political, social, cultural and symbolic power. We will not explore the meta-theoretical differences between Mann and Bourdieu further here; for a thorough introduction to the value of Bourdieu's theoretical approach to journalism studies, see Benson and Neveu (2005).

Briefly, the value of Bourdieu's field theory in social analysis lies in its capacity to recognise on the one hand the patterns and structures of social relations that channel the exercise of power, while engaging with what Corner and Richardson (1993, pp. 222-223) term the pragmatics and contingency of social action, including by journalists. Institutions are routinised patterns of social relations, and therefore loci for contests in the exercise of both collective and distributive power (Mann, following Parsons, in Mann, 1986, p. 6) in any given field of social relations. As such, they are a prime focus of journalistic activity, organised as 'rounds' or 'beats', in the search for and production of news. Tuchman coined the term 'web of facticity' to describe the way news organisations allocate their human and technological resources in space and time to produce the news content for their publications (Tuchman, 1978, pp. 82-103).

Hall et al. (1978, pp. 53-60) analysed these journalistic practices to reveal relations between the important institutional sources ("primary definers') and the media ('secondary definers') as 'structured in dominance'. Such practices were therefore a major factor in the reproduction of existing structures of social power. A number of scholars since then have criticised the 
functionalism of Hall's account, notably Schlesinger (1990, pp. 64-69) and Curran (1996, p. 129), although Davis (2000, p. 45) does point out that the empirical studies since Hall's seminal formulation have confirmed the routine dominance of powerful institutional sources in defining the significance of events and issues in news coverage.

Ericson et al. (1989) formulated an alternative, pluralist analysis of power relations between journalists and their sources drawing on traditions in the sociology of deviance. Their relational approach has many points in common with Hall, most significantly the recognition that in quoting sources (Ericson's 'authorised knowers', as an alternative formulation to Hall's 'primary definers') the media are not only attesting to the 'facticity' of the truth claims, but more importantly attesting to the authority of the sources to make the truth claims and suggest their preferred meanings (Ericson, p.1989: 395). However, Ericson at al. in their research deliberately eschew consideration of the larger structures of social power (Ericson, 1989, p. 3)) and as Hall had earlier pointed out (Hall, 1982, p. 59), this is precisely a weakness with pluralist approaches to social theory. As Schlesinger indicates (1990, p. 78), a strength of Bourdieu's perspective on power in social relations is his capacity to reconcile structure and agency, or what Bourdieu himself termed objectivist and subjectivist approaches (Bourdieu \& Wacquant, 1992, p. 7-9).

The use of sources is a fundamental journalistic activity; sources provide information, bear witness to the truth claims, and authorise interpretations of the significance and meaning of the 'facts'. By reporting their truth claims, journalists not only authorise the claims as newsworthy, but they more importantly authorise the rights of the claimant to make the claim, as 'authorised knowers' in Ericson's framework or as 'primary definers' in Hall's usage. So in our research we have examined what types of sources get coverage or access to assert their truth claims, and on what terms this occurs, ie the levels of competition and diversity between sources, and whether they are presenting the accepted ('orthodox') or challenging ('heterodox') interpretations of the events/issues.

The patterns and routines that appear in these relationships between journalists and their sources contribute to the dynamic 'map of meaning' (Hall, 1978 , p. 54) within which both journalists and their audiences operate (Corner and Richardson, 1993, p. 228-9), and which in turn their activity reproduces. This map might be more dynamically and usefully considered as a 
terrain, within which the protagonists (sources and journalists) operate in contestation as they seek to play their roles and serve their own professional and personal interests according to the rules of the game, or doxa of the field as Bourdieu terms it (Bourdieu \& Wacquant, 1992, pp. 73-4).

Conceptualised as a terrain rather than a map, the shifting points in social space and time of relative advantage and disadvantage in the contest to produce meaning can more readily be sought out, and this in turn intersects very well with what journalists do, wittingly and unwittingly. The news is a constantly shifting depiction and analysis of the play of power on the contested fields of social relations.

Accordingly, in this preliminary scan, we have made a broad brush comparison of our selected newspapers to establish

- what issues get reported, ie what are the presences and absences in the symbolic field produced by the media? At what length and in what terms do issues get reported, ie as news, features, opinion pieces etc?

- what types of sources are used by the journalists to authenticate the truth claims of their reports, which in turn have their own authority authenticated

- the extent of conflict between the accounts of different sources, and what this might reveal about the relationship between the media and other fields of social power (although recognising that conflict is a common, often banal, ingredient in most news narratives).

In a subsequent study currently underway, we are analysing the reporting on ESI in the Vietnamese media, comparing the English language Vietnam News, which is included in this study, with four national Vietnamese language newspapers targeting different demographic readerships. From this we will have an understanding of how ESI are reported by Vietnamese journalists working under a variety of mastheads for a range of readerships in English and Vietnamese, and how this compares with English language reporting of the same subject throughout Southeast Asia.

Apart from its intrinsic interest, the point of this exercise is to generate a research dimension to a programme of collaborative postgraduate teaching in environmental journalism by academics teaching in the journalism programme at the University of Technology, Sydney, and the Academy of Journalism and Communication in Hanoi. It is part of an exercise in research-led teaching, and over time it will include a reflexive study of how this approach to teach- 
ing journalism might impact on the professional practice of students and subsequently graduates who work in the Vietnamese and Australian media.

\section{The empirical research}

We selected a sample of six prominent daily English language newspapers from across the region. They were: Bangkok Post (Thailand), New Straits Times (Malaysia), Vietnam News (Vietnam), Jakarta Post (Indonesia), Manila Bulletin (Philippines), the South China Morning Post (Hong Kong, China). For the same period we did a quick scan of two English-language publications addressed mainly at related Western audiences, the Far East Economic Review, and the Sydney Morning Herald (Sydney, Australia). The last two were added as a point of comparison between Southeast Asian and Western media coverage of the same issues for the same period, but the Far East Economic Review was eventually discarded because the only mention of economic sustainability over the sample period was a single opinion piece arguing against illegal forest logging by the director of a conservation NGO.

We briefly researched the ownership status of all the publications, and any media coverage of changes or controversy over ownership, and reported threats to journalistic independence at any of the publications. Where possible we have included circulation figures and some information about the demographic readership.

Using electronic database records of the publications, we conducted an exhaustive generative search for the period April-May, 2005, starting with the terms 'environment' and 'sustainability' and thence of emergent terms such as 'water', 'forests', 'pollution', 'waste' and so on. We logged and examined all the relevant articles, and then categorised them according to:

- number of words, type of article (news, features, etc)

- subject matter

- number and type of sources

- presentation of sources (direct quotations or paraphrasing were taken to indicate that this was an authoritative statement by the source, and that perhaps the journalist may have spoken to the source directly, and therefore had a chance to ask questions)

- which sources established the 'facticity' and perspective on the story, and whether there was any conflict between sources regarding the interpretation of the story 
- whether there was any follow-up stories (taken as a loose indicator of a news agenda being initiated within the news organisation and not by the source).

We chose two stories from among the most in-depth and multi-sourced stories to analyse further as case studies, one from the Bangkok Post and one from the Vietnam News.

\section{The publications}

Jakarta Post $(J P)^{1}$

With paid circulation of 35,000, this is the largest English language newspaper in Indonesia. It is owned by PT Bina Media Tenggara, an independent newspaper venture formed by three Indonesian media companies in 1982. Its employees hold approximately 20 percent equity in the company. The explicit purpose of the publication is to provide an 'Indonesian perspective to counter the highly unbalanced Western-dominated global traffic of news and views'. About 45 percent of its readership is based in Indonesia, a large proportion of whom are highly educated men working in senior levels of companies and other organisations. More than 20 percent of the rest of its readers are in Europe and around 20 percent are in the rest of Asia. Since 1994, it has been distributed worldwide through international database companies Reuters, Dialog (Knight Ridder) and Chambers Worldnetwork. It has a strong web presence which includes breaking news not covered in the hardcopy edition.

\section{Manila Bulletin $(M B)^{2}$}

The Manila Bulletin, which began in 1900, is the second biggest newspaper in the Philippines, claiming a circulation of around 260,000. It is owned by the Manila Bulletin Company, which also publishes other magazines and newspapers in both English and Filipino languages. The newspaper was one of three that President Ferdinand Marcos allowed to stay open during the period of military rule between 1972 and 1986. Since then there has been an ongoing battle in the Philippines Supreme Court in which Marcos croney 'Danding' Cojuangco has been trying to overturn a court order that he be divested of holdings in the Manila Bulletin that were 'ill gotten wealth'.

Chairman of the Manila Bulletin Company, Emilio Yap, has extensive business interests in hotels, transport and education. In 1999, the Philippines Centre for Investigative Journalism described him as the most interventionist of press proprietors: 'He runs the paper in a manner that some Bulletin edi112 PACIFIC JOURNALISM REVIEW 12 (2) 2006 
tors describe as authoritarian. He approves everyday the lineup of stories for the next day's paper. He also instructs editors on which stories cannot come out and which stories should be prominently displayed' (Philippines Centre for Investigative Journalism, 1999). The centre declared the Bulletin to be a profoundly conservative and uncontroversial paper, which usually supports whoever holds government power.

\section{New Straits Times (NST) $)^{3}$}

The New Straits Times is owned by the Malaysian media corporation Media Prima, which controls 50 percent of the English language newspaper market, two large circulation Malay newspapers, television stations and a radio station. In 2005, it had a circulation of 138,000 and a readership of 295,000, making it the second biggest English language newspaper in Malaysia (Source: Audit Bureau of Circulations, Malaysia: 1 July 2004 - 30 June 2005).

In the 1980s, The New Straits Times passed from government ownership to Fleet Holdings, which was owned by the ruling UMNO party. The current owners of Media Prima are not publicly identified but the company is known to be still close to UMNO. In 2005, The Business Times carried a report stating that a private investment company and the state pension fund manager, the Employees Provident Fund, were among the shareholders (Netto, 2005). The increasing concentration of media ownership and the dominance of Media Prima worries those who argue for a more independent media in Malaysia, although since Prime Minister Abdullah Badawi replaced Dr Mahatmir Mahommed, The New Straits Times, which has been seen to represent mainstream Muslim opinion, has become more liberal in approach and has upset conservative Muslim interests.

\section{South China Morning Post (SCMP)}

The South China Morning Post is owned by Robert Kuok, reputed to be the richest man in Malaysia. Kuok controls Shangri La Hotels, which has more than 40 luxury hotels in Asia, and was once known as the sugar king of Malaysia. He bought the paper from News Ltd in 1993. The paper claimed a daily circulation of 103,000 in 2005. The SCMP is the leading English language newspaper in Hong Kong and targets higher income readers.

Robert Kuok also owns 32 percent of TVB, Hong Kong's leading television station, and has joint magazine interests with US corporation Hearst Magazines. He began investing in mainland China in 1983 where he has 
interests in a Coca Cola bottling plant, a vegetable oil refinery, a hotel chain and property developments.

The South China Morning Post has two main sections, one devoted to national and international news and one for city news that includes sections on lifestyle, entertainment and travel. It has a daily circulation of approximately 120,000 and claims a total readership of more than 250,000. In 2003, its readers were 45 percent female and 55 percent male; 80 percent of readers had post-secondary school education and 69 percent were professionals, managers or executives. The target audience of its print publication was middle to upper class individuals, while its online edition targets a broader audience of internet users interested in mainland China.

Critics of the paper argue that because Kuok was selected in the early 1990s as one of the advisers to Chinese authorities on the future of Hong Kong, he would have taken over the ownership of The South China Morning Post with the blessing of contacts in the Chinese government. As a result, the paper has been perceived as more pro-government (Gomez, 2006, pp.18-20). However the paper is a source of independent news on a range of issues occurring on mainland China.

\section{Vietnam News $(V N N)^{5}$}

Vietnam News is the English language newspaper of the government-owned Vietnam News Agency. It is part of a growing print media market in Vietnam with the number of newspapers and magazines doubling in the last ten years. The newspaper has a circulation of approximately 25,000 readers who are mostly non-Vietnamese business, diplomatic and aid workers resident in Vietnam. Its website is also a key source of up-to-date English language information about Vietnam for audiences outside Vietnam, and it is part of the Asia News Network (http://vietnamnews.vnanet.vn/default.php). While part of the official purpose of the Vietnam News Agency is to communicate government policy to audiences inside and outside Vietnam, its media outlets do reflect community debates and conflict and debates within the government itself. Along with other Vietnamese print media, Vietnam News has recently been reporting more actively on corruption, although there are concerns that a recent media decree may limit increasing signs of press independence (New decree seen as threat to Vietnam's nascent press freedom, Agence France-Presse, 2 July 2006). 
Bangkok Post $(B P)^{6}$

The Bangkok Post is the biggest and oldest English language newspaper published in Thailand. It was first published in 1946 and is now owned by the Post Publishing Company in which the family of Suthikiati Chirathivat holds a controlling interest. Chirathivat has extensive business interests, including in the Thai resort industry. Robert Kuok's South China Morning Post Ltd owns more than 20 percent of the company. Australian journalist David Armstrong, who was editor-in-chief of News Ltd's rightwing national newspaper The Australian until 2003, is deputy chief executive officer of the Post Publishing Company Ltd and director (editorial) of South China Morning Post Publishers Ltd. Last year, there was an attempted takeover of the Bangkok Post by Paiboon Damrongchaitham, who controls the entertainment giant GMM Grammy, which owns 12 Thai radio stations and television stations. As well as building up his interest in the Post Publishing to more than 20 percent, Paiboon also bought a 30 percent stake in Matichon, which owns several large Thai newspapers. He has been described as a friend of Prime Minister Thaksin Shinawatra, who has been regularly criticised by the Bangkok Post and other media outlets. The Bangkok Post journalists, supported by the Thai Journalists Association, campaigned against the GMM Grammy takeover claiming it would 'endanger the public interest and policymaking' (Giahan, 2005). Chirathivat refused to sell his shares to GMM Grammy and sought the assistance of Robert Kuok's South China Morning Post Ltd in thwarting the takeover. The Bangkok Post, which has a circulation of approximately 70,000 , claims its reach extends to 450,000 readers who are affluent and well-educated.

\section{The Sydney Morning Herald $(\mathrm{SMH})^{7}$}

The Sydney Morning Herald is one of two daily newspapers in Australia's biggest city, Sydney. It is Sydney's only metropolitan broadsheet newspaper (the News Ltd national broadsheet The Australian is also available) and with a circulation of around 220,000, sells far less than its tabloid competitor The Daily Telegraph, also owned by News Ltd. Its actual readership is estimated at about 850,000 with more than a million reading its weekend edition. The target audience is in the 'AB' demographic with above average income and education levels, and working as managers, professionals and executives. It covers national and international news but has a strong Sydney focus with 
daily consumer-oriented lifestyle sections.

The Herald has been continuously published since the 1830s and until 1990 was owned by the Fairfax family. It is now owned by the public company John Fairfax and Sons, which also owns The Australian Financial Review and the Melbourne broadsheet The Age. The company has been actively building its extensive Australian regional and suburban print interests and its internet arm, Fairfax digital. In 2003, it took over New Zealand's Independent Newspapers Ltd to become the largest print media company in New Zealand, where it now owns the Dominion Post in Wellington and eight other daily newspapers. The Australian government is currently proposing to change media ownership laws to allow more foreign ownership and to allow television, print and radio outlets to be owned in the one media market, which has not previously been permitted. If these changes proceed, Fairfax itself is regarded as a likely take-over target (Kruger, 2006).

\section{The stories}

Overall, there was a general similarity in the types of and approaches to stories on ESI. Interestingly, the only coverage of ESI that queried the implicit assumption that the environment required strong protective measures was in The Sydney Morning Herald, which ran a major opinion piece by a right wing columnist querying the evidence on global warming. The following list of headlines from the Vietnam News is generally typical of the way stories were presented across all mastheads, namely that effective environmental conservation and protection are taken to be a desirable and necessary goal, and are relevant to a broad range of political, economic and social activities and policy concerns:

\section{Vietnam News: April 2005}

'Exploitation of river sand leading to more landslides'

'Nha Trang hosts environment, tourism meeting'

'Seahorse under threat of extinction in Phu Yen, say environment experts'

'Can Gio forest under further threat from drought, infestation'

'Environmental education focuses on water theme'

'Country targets policies for sustainable water resources'

'Water management to be major challenge in coming decades' 
ECO-JOURNALISM AND SECURITY

'Management problems challenge Can Gio mangrove forest protection efforts'

'Red-headed cranes return to southern Tay Ninh Province'

'Germany provides aid for salt-marsh development'

'Deputy PM urges protection against deforestation, fires'

'Ha Long Bay under threat of illegal oil trade'

'Environmental protection needed to sustain development: PM Khai'

'Derelict pipes blamed for water quality'

'Protect shrinking groundwater resources to battle drought'

'PM gives green light to foreign resort developer'

'Forest initiative calls for projects'

Vietnam News: May 2005

'Environmental contest receives $14 \mathrm{VN}$ entries'

'Four factories suspended for polluting environment'

'Fisheries sector considers environment'

'Fisheries need more control'

'Outlook focuses on VN's environmental protection'

'Viet Nam's big cities suffer from serious air pollution'

'Delta animal breeders degrade environment'

'Conservation fund to grant support to national parks'

'HCM City offers incentives for polluting enterprises to relocate'

'SIDA helps VN manage land'

'Con Co Island's natural resources in danger'

'Rare flora found in mountainous province'

'Hotline established to protect wildlife'

'Mekong ministers to meet in Shanghai'

'Hai Phong considers greener expansion'

'IZs, EPZs develop despite hurdles'

'Khanh Hoa destroys starfish to protect coral'

'City to move 27 pollution causing enterprises'

'Scientists petition UNESCO for Ba Be heritage inclusion'

'Viet Nam, Cuba to join in biotech, environment efforts'

Figure 1 gives the comparison of the amount of coverage, and Table 1 gives more detailed statistics on the type of coverage. The Jakarta Post had the most stories followed by The South China Morning Post, while the Manila 
ECO-JOURNALISM AND SECURITY

Bulletin had the least stories, and the other papers, including The Sydney Morning Herald, had between 36 and 54 in total.

As well as most stories, the Jakarta Post also had the highest proportion of non-news coverage, followed by the Vietnam News (Figure 2). The New Straits Times, with the second lowest average word count, also had the highest proportion of news stories. The Sydney Morning Herald was roughly comparable to the Bangkok Post and The South China Morning Post in its balance between the two genres.

Regarding subject matter, there was a wide variety. Table 2 and Figure 3 set out the subjects that generated more than 5 percent of the total coverage for any one paper. Interestingly, there is a fairly even balance in The Sydney

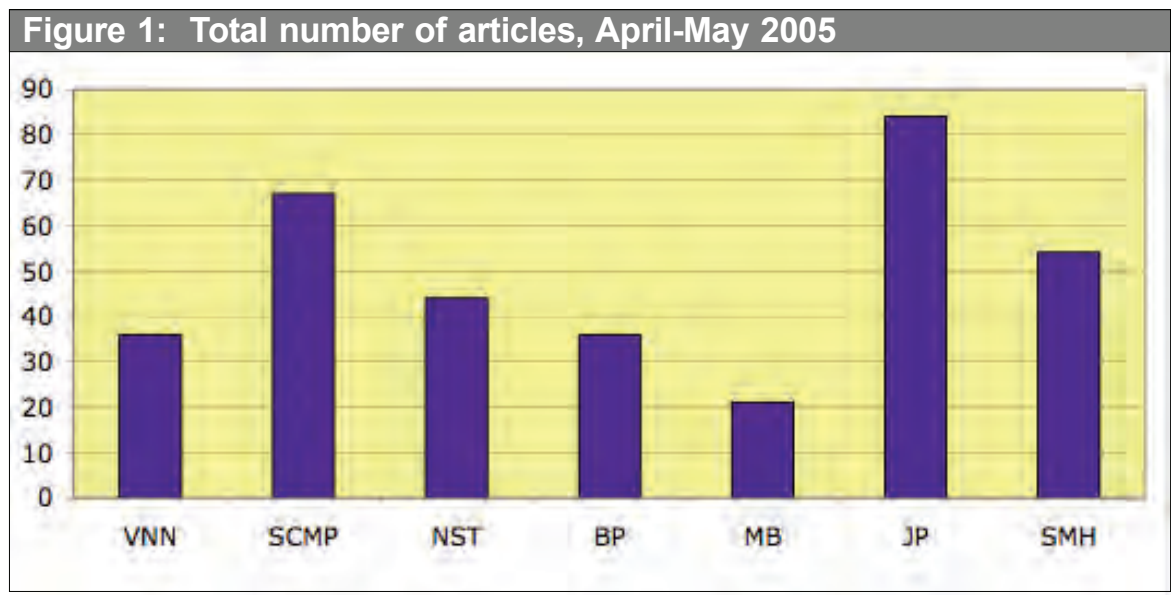

\section{Table 1: Statistics on the type of coverage}

\section{Articles}

Total number

Maximum per day

Average word count

Ratio of news articles to others

$\begin{array}{lllllll}\text { VNN } & \text { SCMP } & \text { NST } & \text { BP } & \text { MB } & \text { JP } & \text { SMH } \\ 36 & 67 & 44 & 36 & 21 & 84 & 54 \\ 3 & 4 & 3 & 3 & 3 & 5 & 6 \\ 322 & 491 & 343 & 471 & 503 & 480 & 768 \\ 2.89 & 5.09 & 22.5 & 5 & 9.5 & 1.8 & 4.2\end{array}$

Morning Herald, but a much wider variation in the Asian papers, with water and forests far outstripping the other topics everywhere except in the Manila Bulletin, which registered no coverage of forests, and where water was its third ranking focus. Events, a category denoting stage-managed public rela- 


\section{Figure 2: Percentage of non-news articles, May-June 2005}

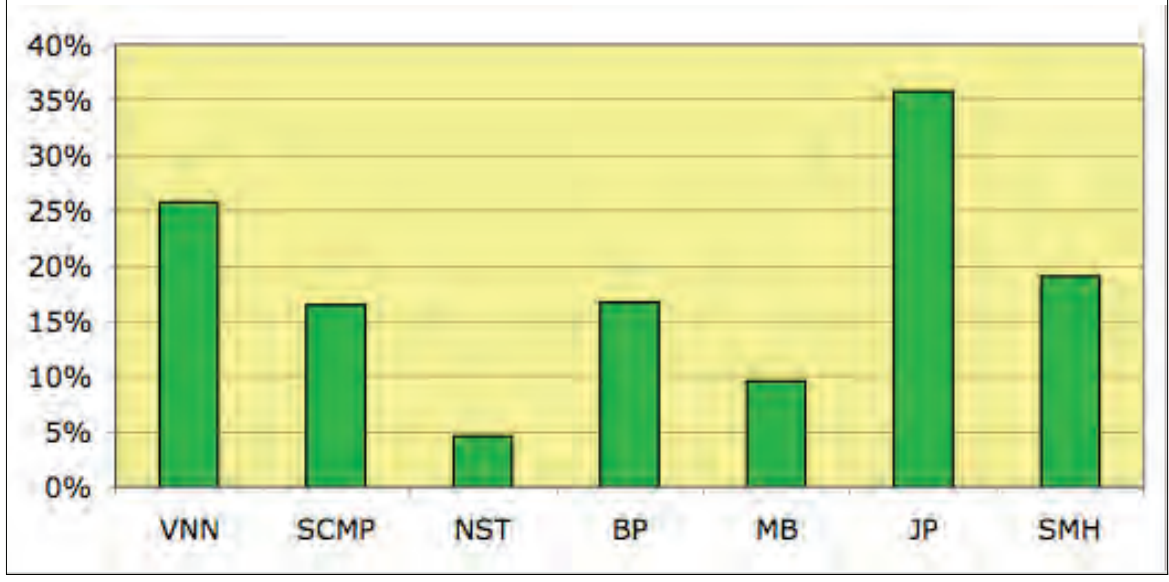

tions activities such as tree plantings, festivals, etc. occupied one fifth of all Manila Bulletin coverage of ESI, one-tenth of Vietnam News coverage, and 5 percent of the Bangkok Post ESI reporting, but did not register with the other newspapers, including The Sydney Morning Herald. PR events generally would be seen by journalists as 'soft news', and as a way of covering the environment without engaging with the 'hard' aspects of conflict and accountability.

All newspapers had a similar level of coverage of corporate activities, apart from the Bangkok Post and Sydney Morning Herald, where there was no significant level of coverage in the period. The coverage of waste as an issue was greatest at The Sydney Morning Herald, and didn't register in the Bangkok Post or Vietnam News. The Manila Bulletin covered the widest range of issues, albeit with the lowest overall number of stories, which might suggest a relatively superficial level of coverage as opposed to more focused and frequent coverage.

As indicated in the earlier theoretical discussion, the relationship between journalists and their sources is a crucial locus of the negotiation and exercise of power in the symbolic and ideological fields of mediated representation. If sources are not quoted at all, there may be a variety of reasons. For example, the journalist or newspaper might be asserting their own authority as witness to the events or processes being reported, or alternatively the source of the claims in the article might be hidden to disguise accountability for the occurrences. Either way, normal, and (one might assert) good journalistic practice 


\section{Table 2: Subject matter $>5 \%$ of total}

$\begin{array}{llllllll}\text { Subject } & \text { VNN } & \text { SCMP } & \text { NST } & \text { BP } & \text { MB } & \text { JP } & \text { SMH } \\ \text { Water } & 31 \% & 24 \% & 20 \% & 15 \% & 0 \% & 14 \% & 15 \% \\ \text { Forest } & 14 \% & - & 34 \% & 36 \% & 10 \% & 36 \% & 15 \% \\ \text { Air } & - & 15 \% & - & 8 \% & 10 \% & 6 \% & 13 \% \\ \text { Land } & - & - & - & 5 \% & 5 \% & - & - \\ \text { Energy } & - & 7 \% & - & - & 5 \% & - & 11 \% \\ \text { Flora/fauna } & 11 \% & - & - & - & 0 \% & 6 \% & 9 \% \\ \text { Events } & 11 \% & - & - & 6 \% & 19 \% & - & - \\ \text { Companies } & 8 \% & 7 \% & 7 \% & - & 5 \% & 7 \% & - \\ \text { Global warming } & - & - & - & - & 5 \% & - & 6 \% \\ \text { Waste } & - & 12 \% & 7 \% & - & 14 \% & 11 \% & 17 \% \\ \text { Other } & 17 \% & 25 \% & 25 \% & 19 \% & 29 \% & 11 \% & 7 \%\end{array}$

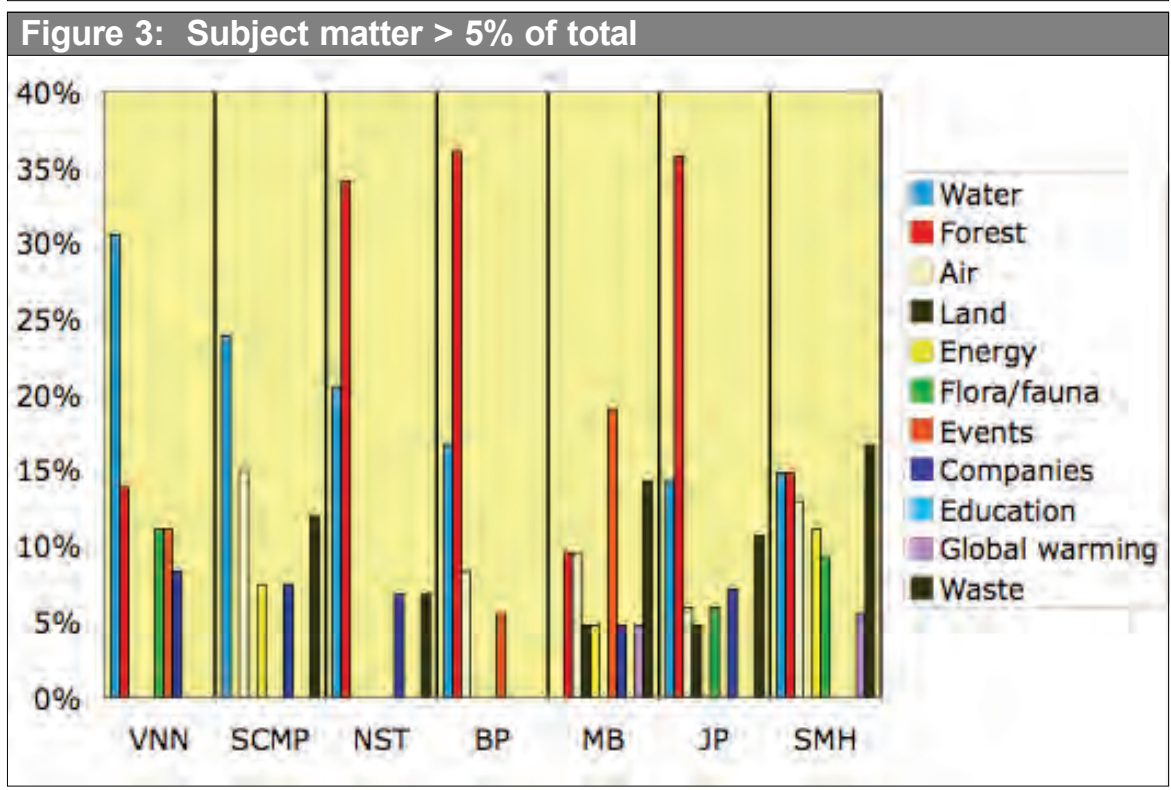

in pursuit of the public right to know (Nash, 2003, p. 3), is to identify the sources (or at least report their confidential existence) so that readers might draw their own conclusions as to the authority and likely veracity of the truth claims. Futhermore, journalists ought to be informed consequentially as to who might be properly held accountable for the reported events/processes.

Figure 4 depicts the percentage of stories lacking either a directly quoted or paraphrased source. The highest level of unsourced stories occurred in the 120 PACIFIC JOURNALISM REVIEW 12 (2) 2006 
Vietnam News, followed by the Manila Bulletin, the lowest number in the Bangkok Post, followed closely by The South China Morning Post.

Figure 5 depicts the types of sources that were quoted, and Figure 6 depicts the same information in a different way, by type of sources rather than masthead on the horizontal axis. As expected (Tuchman, 1978; Hall, 1978; Ericson, 1989), official and representative sources from one sector or another far outweighed, by a ratio of at least four to one, non-official sources. The least usage of lay or non-official sources was in the Manila Bulletin, while the highest usage was in the New Straits Times and Jakarta Post. We have distinguished between government and political sources (as between responsible bureaucratic functionaries and party-political representatives), but this division would have ambiguous value in one-party states such as China and Vietnam. The highest use of government sources was in the Manila Bulletin,

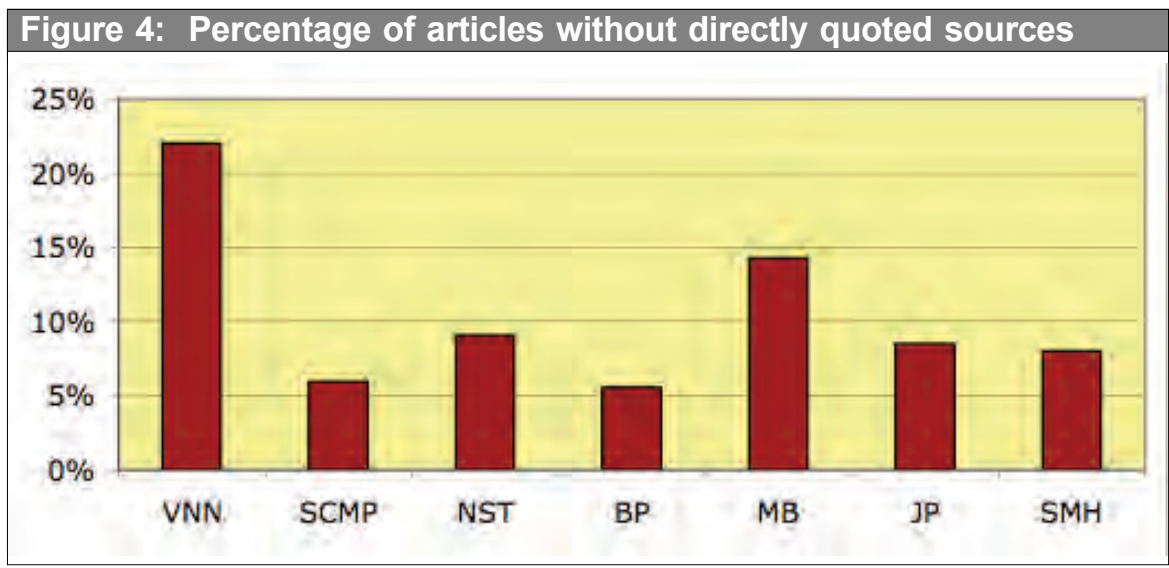

but it quoted no political or company sources in its coverage over the period, which would suggest a reluctance to posit political and corporate accountability for the events/processes being reported. This in turn amplifies the inference from the high level of coverage of PR events at the Manila Bulletin: that this newspaper is the most reluctant to canvas hard issues of political and corporate accountability in its reporting.

The Vietnam News, on the other hand, had the highest usage of political sources and no usage of company sources, and the second highest usage of government sources, as one might expect in a party-state. The case study below will explore some of the ways in which government sources were used 
in one Vietnam News story, but the lack of company sources suggests a reluctance, if not a prohibition, on the part of the paper to address issues of accountability in the economic field regarding ESI. On the other hand, The South China Morning Post used the highest number of company sources, a very low number of political sources, and an average number of government sources. The China-Vietnam comparison suggests interesting differences of approach between privately-owned and state-owned media in one-party states, with perhaps each form of ownership preferring to operate journalistically in its own field (the economic and political fields respectively), where they might feel more comfortable and secure playing the game to their advantage.

Interestingly, the Jakarta Post, perhaps the most outspoken of the newspapers in our sample, used the least number of government sources, almost no political sources, and the highest number of NGO, lay (unofficial) and other sources. They also had the second highest number of company sources, suggesting a strong focus on corporate accountability to communities, adoption of a grass roots 'voice' (Hall, 1978, p. 63) and a disregarding of political accountability. The New Straits Times was around the middle of the sample on the use of most sources, except for a very low usage of experts.

Where only one source is quoted, that source typically has a "primary

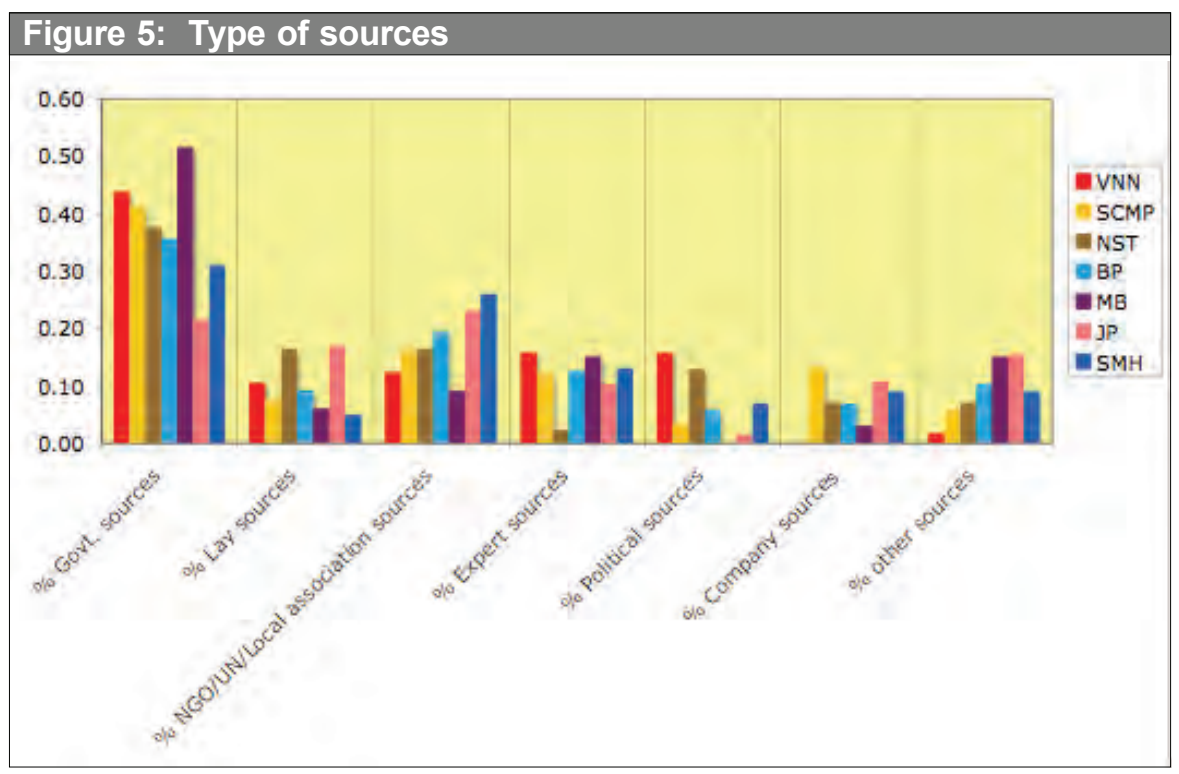

122 PACIFIC JOURNALISM REVIEW 12 (2) 2006 
definer' or 'authorised knower' status to set the preferred interpretation of the story. One indicator of an assertive press is where articles quote multiple sources that compete over definitions and interpretations of the events/processes/issues being reported. Figure 7 depicts the results for our sample on this measure. The Manila Bulletin had the lowest proportion, at under 10 percent, while the highest usage of competing sources was made by The South China Morning Post. The other four mastheads, including the Vietnam News, had a roughly equal usage at around 15 percent of total articles. Putting this information together with the statistics in Figures 5 and 6, it is apparent that official sources overwhelm (or over-access, to use Hall's term [Hall, 1978,

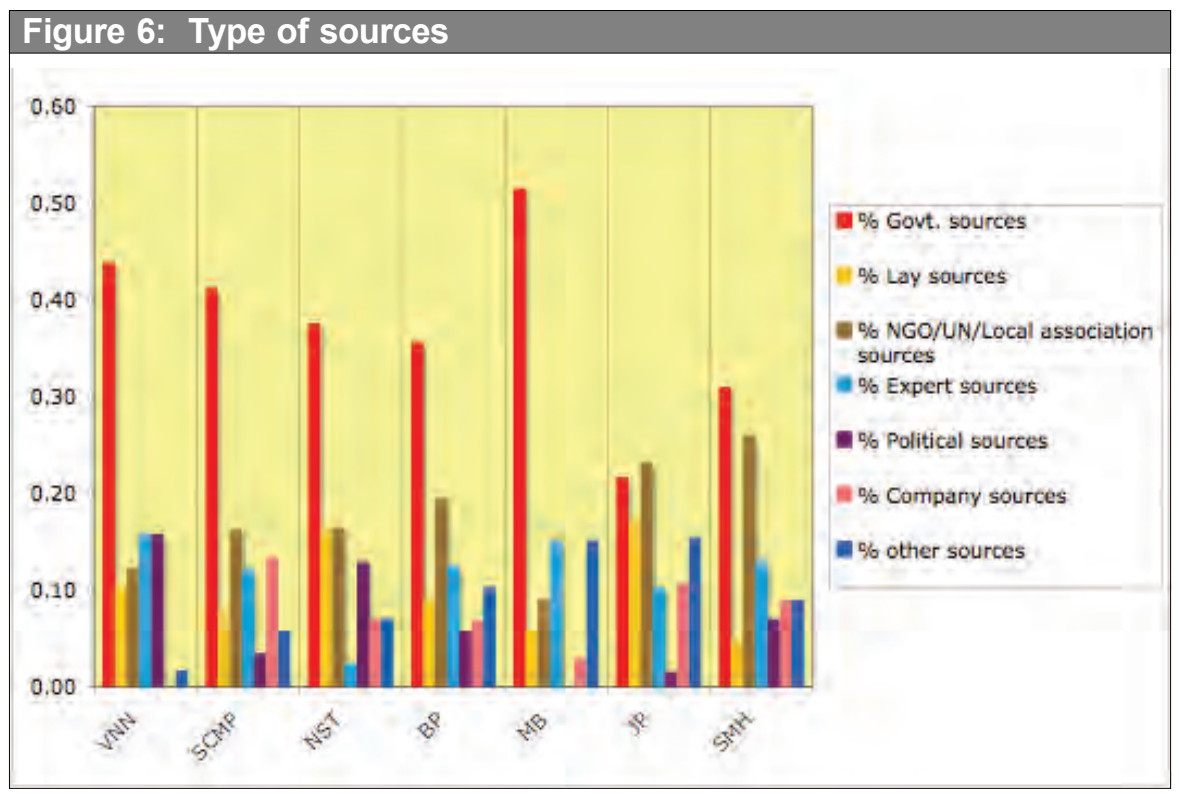

p. 58]) all others in their capacity to define the terms of most stories. In most individual instances, pace Schlesinger's valid argument about competition among official sources (Schlesinger, 1990, p. 66), they do it unchallenged by alternative interpretations from other sources, official or non-official.

Another indicator of journalistic assertiveness is the rate of follow-up stories, depicted in Figure 8. This is not a simple indicator, and like all of them has to be read in conjunction with the other indicators, as well as with reference to other factors. Again, it was the Manila Bulletin that had no 
follow-up stories, while the highest proportion was achieved by The New Straits Times, perhaps as a corollorary of their strong focus on short news items. The Bangkok Post and Jakarta Post, perhaps because of their stronger emphasis on campaigning journalism, were the next highest scoring, but with only 8 percent and 4 percent of total stories. The South China Morning Post matched the Jakarta Post, while the Vietnam News, perhaps partly because of its use of features, had about 3 percent of its stories as follow-ups. Not too

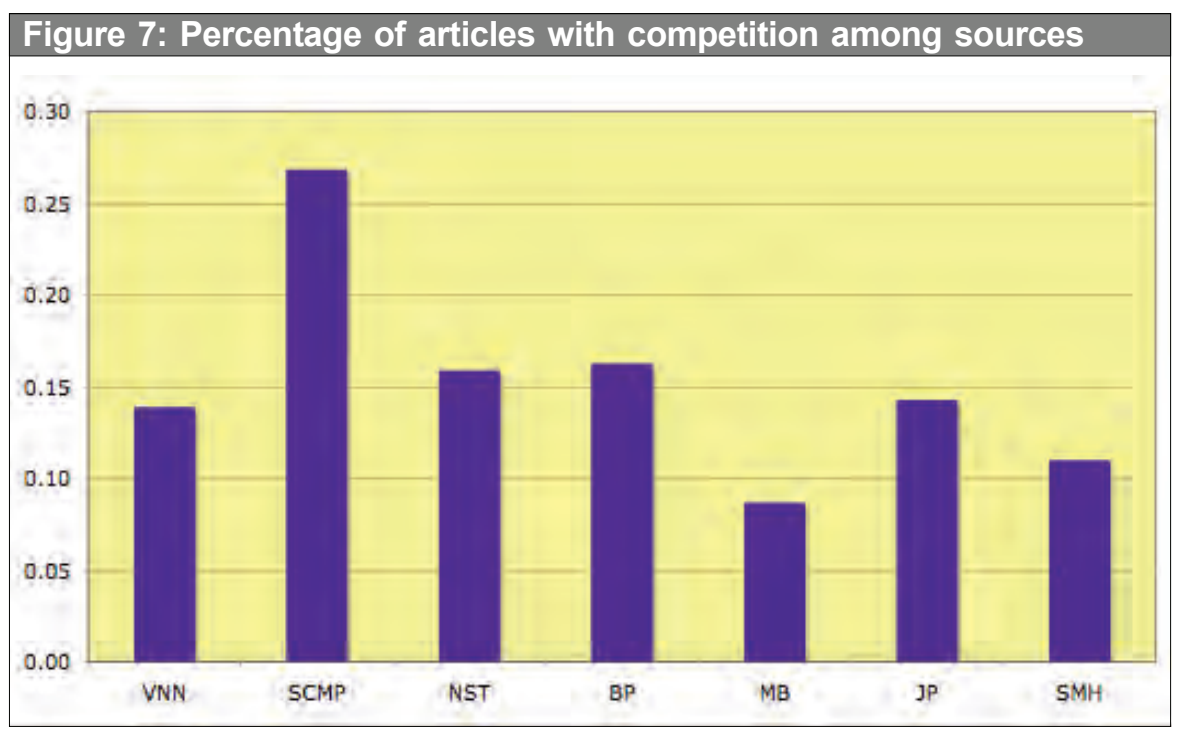

much should be read into these figures, because of the short time frame (two months: April-May 2005) and the very small number of stories, as listed in Table 3. Interestingly, 12 out of 15 follow-ups (80 percent), spread across four different mastheads, were on pollution stories, which did not rate as a category on our chart in Figure 3 because it rated less than 5 percent of stories in any of the different publications. This confirms that the different quantified measures should not be read in isolation, but need to be appreciated as part of larger patterns reflecting an intersecting array of complex factors. Individual case studies can provide further insights into how these factors can play out in actual stories, and we turn now to two examples, both complex multi-sourced stories, one with the Bangkok Post and the other with the Vietnam News. 


\section{Case studies}

\section{Bangkok Post: Illegal shrimp farming}

The Bangkok Post case study comprised five separate articles, published in April 2005, about allegedly illegal shrimp farming activities of Thailand's largest agribusiness company Charoen Pokphand Group (CP) on the Rayong Coast in southern Thailand.

CP has an annual turnover of more than \$US13 billion, has interests in feed production, petrochemicals, and telecommunications throughout Asia and the US, and uses the motto 'Kitchen of the World' for its food production. In 2003, CEO Dhanin Chearavanont was listed among Fortune magazine's 25 most powerful people in business outside the US. It is the world's biggest exporter of Black Tiger shrimp. None of this above information was included

\section{Figure 8: Statistics on the type of coverage}

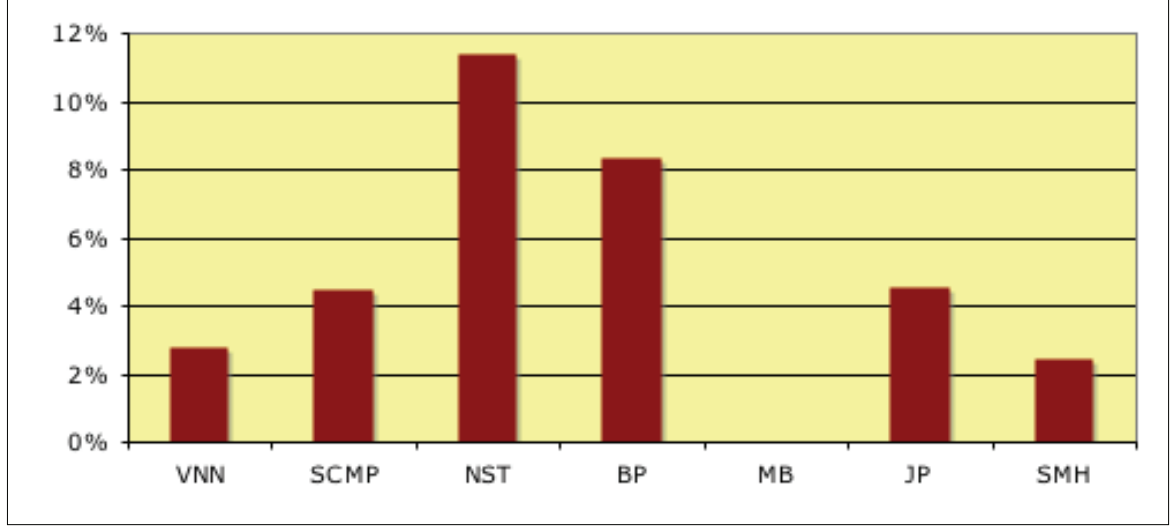

\section{Table 3: Followed-up stories}

\section{Followed-up stories}

Vietnam News

New Straits Times

South China Morning Post

Bangkok Post

Jakarta Post

Sydney Morning Herald
Forests (1)

Forests (2), Pollution (2)

Water (1), Pollution (2)

Forests (1), Pollution (2)

Forests (2), Pollution (2)

Energy (4), Waste (1) 
in the Bangkok Post articles, though perhaps some of it was known to some of the Post's readers.

On 21 April 2005, the Bangkok Post's story was headlined 'CP Group 'invaded forest'; Senate panel says it will take legal action'. The paper reported that the chairperson of the Thai Senate Environmental Committee and opponent of the Thaksin government, Senator Kaewsan Atipho, had reported to police that satellite images proved that the CP Group had invaded 'large stretches of mangrove forest'. He was quoted as accusing the company of conspiring with local authorities to forge title deeds to gain access to public land containing centuries-old mangrove forest. He gave the Provincial Governor 60 days to revoke CP's allegedly forged deeds. 'Do not start hiring gunmen because if the villagers are dead, it will make no difference. We will still press for justice,' Kaewsan warned.

The rest of the article is strongly supportive of the Senator's stance. The article's second source was a Senate panel member who supported the views of Senator Atipho. The story is backgrounded with the information that $\mathrm{CP}$ group is one of the ruling party's (Thai Rak Thai) largest financial supporters, and its owner Dhanin Chearavanont was former adviser to the finance minister during Prime Minister Thaksin Shinawatra's first term in office. Current Industry Minister Watana Muangsook is Dhanin's nephew-in-law.

A third source and counter definer is a CP company spokesperson who denied the accusations. He gives the explanation that residents were only complaining because previous illegal moonshining activities had been stopped. A fourth and final source, the Thai Natural Resources and Environment Minister, declared war on forest encroachment, giving the strong impression that the Senator's allegations were credible. So in total, three out of the four sources in the first story supported the 'facticity' of CP's wrongdoing, and the only quoted defence to the charge was a threadbare denial and scarcely credible counter-claim.

A second story appeared on the following day (April 22, 2005), headlined 'Land check finds proof against CP; Mangroves acquired unlawfullyofficials', and reporting that the National Resources and Environment Minister had confirmed the encroachment. A second source, Mangrove Conservation Chief Paisarm Tanapermpool, also confirmed that some plots of land have been obtained illegally. He called on CP to do the 'right thing' and hand back land. 
Once again, the article includes the denial by the CP company spokesperson. This was followed, however, by a third source, a local policeman who also confirmed that illegal activity had occurred, once again leaving readers in little doubt that the paper believed CP had acted illegally. Again, there was a ratio of three sources to one against $\mathrm{CP}$.

A third story ('Commentary: A time for courage') which appeared two days later (April 24, 2005) was an opinion piece by Senate member Thongbai Thongpao. He warned that local officials do not always take action even when there is corruption because 'tycoons' (a negative choice of word) may exert 'dark influences' over officials. The opinion piece provided more background, alleging that earlier in 2005, after CP hired contractors to destroy the forest for shrimp farms, 400 households that were helping preserve the forest had complained without success. He called for police and for the Minister to keep their word to act.

The opinion piece was followed by a fourth article which was another opinion piece ('Commentary: Lacking what it takes for social responsibility'), by deputy editor Veera Prateepchaikul. This was very supportive of the villagers whom he compares to 'an environmentally conscious princess planting saplings'. This piece placed the conflict in the broader political context of tensions between the Senate and the Thaksin government, the CP and the local governor and argued that the most important question is 'the social responsibility of major corporations'. These two opinion pieces could be read as confirming the political power of the opponents to CP's actions, and amplifying the terms of the attack.

A fifth and final article ('RAYONG / DWINDLING MANGROVES; Public forum to counter forest encroachment') on 26 April 2005 reported that a former Rayong mayor was planning a public forum which would look at the broader issue of mangrove encroachment in local tambons to be 'aimed at feeding facts to the public'. In this article an affected villager is also quoted and there is yet another reference to the company denial. The Senator is then quoted again. Again, there were three sources to one against CP.

Considered together, the reports represent a strong example of campaigning environmental journalism. Authoritative sources in the form of senior politicians establish the 'facticity' of the situation with its political, legal and moral dimensions, and make suggestions about the previous and potential future behaviour of the alleged culprit, CP Group, that involve serious ille- 
gality, including the threat of murder. The sequential structure of the stories builds the pressure on the company, culminating in threats of further public activism.

The story itself and the plight of the villagers then disappeared from the news, and indeed there is no further reference to the issue in the Bangkok Post or elsewhere on the English language web. It may be, however unlikely, that the issue was resolved to the satisfaction of the local communities, but readers could also get the impression that it only achieved brief prominence because of its broader relevance to the news agenda of political tensions between the Thaksin government, the Bangkok Post and other Thai media (Tejapira, 2006).

The story achieved a wider exposure by being republished on the Mangrove Action Project website in Thailand and on seafood industry websites in Norway and Australia (www.growfish.com.au/) At no stage however was this local shrimp farming story connected to the larger economic story of shrimp farming or the other agribusiness multinational activities of CP. (Mangrove Action Project www.earthisland.org/MAP/ltfrn_154.htm)

Arguably, the five stories constituted a fierce assault in the symbolic field of the media, and are now archived for reference purposes on various web sites. The strategy of the accused protagonists, corporate and political, was to absorb the accusations with minimal contestation, and wait for the temporal cycle of news coverage to move on, leaving them still in a dominant position economically and politically in this matter. This perspective would bear out Schlesinger's point (Schesinger, 1990) that to effectively analyse media power it is necessary to decentre the media, and consider the broader webs of social power relations.

\section{Vietnam News: Illegal oil trade in Ha Long Bay.}

Our second case study is a single article 'Ha Long Bay under threat of illegal oil trade' which was published on 22 April 2005. The story begins with a strong lead summary paragraph:

The rampant and unrestricted sale of oil and gas on Ha Long Bay is posing a mounting environmental threat to what is arguably the most widely recognised of Vietnam's world heritage sites.

The first source quoted is an unnamed Australian tourist: 
'They are bombs,' said one worried Australian visitor while pointing her index finger toward the nearly ten tankers dotting the bay. This tourist refused to climb onto a tour boat.

The statement that '[h]er worries may be well-founded', which begins the third paragraph, adds credibility to the unnamed source and is followed by the statement:

An inspection conducted last year by Quang Ninh Trade Department on 24 large and small tankers found that as many as 23 were in violation of safety regulations. Many large tankers were equipped with neither special safety buoys to avoid oil spills nor a system of waste collection to treat discharged water. Some small tankers did not even have operating licences.

A government source in the local Trade Department then responded:

oil tankers have been brought under increased legal control. Now, only 17 oil tankers are allowed to sell oil on the bay.

Using a strategy that undermined the authority of this official statement, the reporter responded relying on his or her own observations:

Nevertheless, the casual observer might shiver with fear to look at some such tankers, many of which appear completely deserted.

Another trade official is then quoted as pointing out that 'under regulations [three crew members] must keep watch on the boat to prevent mishaps'. The article goes on to refer to another regulation that allows only boats of more than 100 tonnes to sell petrol on Ha Long Bay. 'In fact', the article reported that more than half of 17 boats on the bay were less than 100 tonnes.

To support the proposition that the use of small boats was dangerous, the article quoted another government source, this time an environmental one:

Although each boat carries no more than 1 tonne of oil, it would be impossible to control the consequences if an accident were to occur. Normally, these boats go ashore to get oil at the first light of day or in early evening. They carry oil in drums. Smaller boats made of bamboo 
lath also buy oil on shore and then re-sell it to those boats that specialise in peddling oil at sea.

Providing balance which places the small boat trade in a broader context, the article then quoted a local army official who argues that more control will only open the way to competitors from a nearby province:

Demand stimulates supply .... [b]ut the livelihoods of more than one thousand households in fishing villages all throughout the bay are at risk if boats peddling oil are not allowed to operate.

In a subtle way, this economic argument has already been undercut by the unnamed tourist who preferred not to use a tourist boat that threatened the ecology of the bay and conceivably the safety of tourists. But although three officials are quoted as arguing that controls should only be applied cautiously, the reporter returns to the environmental official:

'A strict stance must be taken to prohibit the sale,' argued Duoc. 'Small boats selling oil on the water are a dangerous threat to the bay's ecology.'

Having once again undercut the other officials, the Vietnam News finished the article with a short comment:

For the time being, a unified system of regulation for this valued world heritage site has not yet been completed. The trade in oil and petrol also awaits regulation.

This article, like the articles in the previous case study, adopts a clear authorial position that challenges the executive government line. It does this by relying on the reporter's own observations, and adds credibility and colour by reporting the reactions of an unnamed source from among the economically desirable foreign tourist trade, whose statements frame the 'facticity' of the danger from the oil. The report then sets up a competition between three government sources downplaying the problem and one environmental official who supports the tourist's perception. The author's viewpoint gets the last word, by returning for a second quote from the environmental official 
and supporting that comment with the reporter's own conclusion. The story has a subtle structure of balancing points of view within a larger frame of clear intent and meaning. In contrast to the first case study, the "primary definer' or 'authorised knower' is an un-named source, compared to a senior politician, and rather than the weight in numbers and prestige or capital of sources being on the side of the primary definer, it is opposed to the primary definer in numbers and political authority. From this perspective, the narrative assertion of independence by the journalist is more marked in the second case study than in the first, albeit in a situation where there are no threats of murder in the air. On the other hand, such a strategy may have been necessary for the Vietnam News to be able to argue to its owners that the political sources had been given a more than fair hearing.

\section{Concluding comments}

As a preliminary scan, using a non-randomly chosen sample of newspapers over a limited period of time, there are clear constraints on the applicability of any conclusions we might draw. However, there are some salient points that can be noted.

Firstly, the relationship between the political economy of media ownership and journalistic content is complicated, and no simple dichotomies relating to state vs private sector ownership seem applicable. In classic liberal theory, private sector ownership is essential to ensure independence from the state, whereas in classic socialist theory, the state ownership in some form is necessary as a bulwark against the depredations of economic capital. But in this study the least critical masthead regarding political and government accountability on ESI was the privately owned Manila Bulletin, while the stateowned Vietnam News sat in the mainstream of regional coverage of ESI, and on occasion reported conflict between government sources, and gave more credibility to sources opposing government positions. The Sydney Morning Herald was not markedly distinctive or noteworthy in its coverage of ESI relative to the range of newspapers in the sample, and its language and inferences in political commentary are certainly less robust than that of the Bangkok Post and Jakarta Post.

Further, there are complex patterns of intersecting private ownership, crossing national borders and engaging both capitalist and communist governments in multi-dimensional relationships of an economic and political 
nature. Some of the private sector oligopolies have extensive business interests in economic sectors beyond the media, just as governments have extensive economic interests, so the potential for conflicts of interest at the ownership level are huge in both cases. Politically, while state-owned media are not known for radical attacks on the political foundations of communist rule, nor are media owned by private capital known for criticising the fundamentals of capitalism. It is certainly arguable that large corporate interests pose a threat to journalistic independence comparable to state power, if not greater because of their transnational reach (Davis, 2000).

This is not to say that different forms of media ownership are equally benign with respect to the independence of journalism, nor that polities and citizens would not be better served by forms of media ownership that buttressed and safe-guarded the independence and public accountability of journalism. But it is to say that Cold War polarities in rhetoric have little analytical value.

Secondly, there is at the same time both a region-wide diffusion of a common set of professional practices and principles that make journalism a distinctive and definable activity across the boundaries of nations and political systems, and yet a wide diversity in the routine implementation of those practices. While the subject matter and use of sources by the Manila Bulletin might seem consonant with the interests of a deeply conservative and collaborationist corporate ownership, the differences between the Bangkok Post and Jakarta Post on their use of political and government sources is much more difficult to predict from broad principles. The same can be said about contrasting preferences for news and feature journalism by the New Straits Times and The South China Morning Post. To establish the causes and consequences of these divergences will require much more detailed research into the specificities of each masthead's field of operations.

Thirdly, environmental journalism as a distinctive field of journalistic practice (Hansen, 1993) is now well-established across the English-language media of Southeast Asia. Indeed, protection of the environment has now achieved 'motherhood' status, and so the terms of contestation in its reporting and analysis among sources and journalists have shifted onto a different terrain. In Manila the Bulletin observes the form of environmental coverage, but it is at the extreme 'soft' end of the spectrum in terms of reporting political and corporate accountability. In Vietnam, the significance of the environment provided an opportunity for the Vietnam News to challenge the argu- 
ments of government officials with the views of an anonymous foreign tourist. In Bangkok and Jakarta the language is robust and the news is 'hard', but that doesn't necessarily guarantee the adequacy of the coverage of ecological issues confronting societies locally or globally.

The symbolic field of media representation has its own rules or doxa, including its own institutional forms and rhythms of production in space and time. Despite the motherhood status of environmental sustainability within the media, there is no reason to believe the ecological situation is getting any better in Southeast Asia, nor in Australia as reported on by The Sydney Morning Herald. Stories come and go, and running dead with a minimalist or diversionary response on an issue while the media attention passes is a tried and true communication management strategy for governments and corporations. Perhaps this thinking lies behind the reluctance of the Jakarta Post to make much use of government and political sources in its campaigning approach to environmental issues.

As then Australian Prime Minister Paul Keating once put it: the dogs bark and the caravan moves on ('Labor in Power', ABC-TV, 1993). It is ascertaining the relationship between the barking and the movement that is of interest for further research.

\section{Notes}

1 This information is drawn from the Jakarta Post website at www.thejakartapost.com/adsspecial/medkit06/fast_facts.html (accessed July 2006)

2 www.mb.com.ph

3 www.nst.com.my

4 www.scmp.com

$5 \mathrm{http} / / /$ vietnamnews.vnagency.com.vn

6 www.bangkokpost.com

7 www.smh.com.au

\section{References}

Asia Media-South China Morning Post UCLAAsia Institute: www.asiamedia.ucla.edu/ article.asp?parentid $=28038$ (accessed July 2006)

Benson, R. and Neveu, E. (2005). Bourdieu and the journalistic field. Cambridge, UK: Polity Press.

Bourdieu, P. and Wacquant, L. (1992). An invitation to reflexive sociology. Cambridge: UK: Polity Press. 


\section{ECO-JOURNALISM AND SECURITY}

Corner, J. and Richardson, K. (1993). Environmental communication and the contingency of meaning: a research note. In Hansen, A. (Ed). The mass media and environmental issues. Leicester: Leicester University Press.

Davis, A. (2000). Public relations, news structures and changing patterns of source access in the British national media. Media, Culture \& Society. 22(1): 39-59

Ericson, R. et al. (1989). Negotiating control: a study of news sources. Milton Keynes: Open University Press.

Giahan, S. (2005, September 20). Thailand: Inching closer to media monopoly. Asia Media Forum. http://www.asiamediaforum.org/node/302

Gomez, E. (2006). Malaysian investments in China: Transnationalism and the Chineseness of enterprise development. Asia Research Centre, CBS, Copenhagen Discussion Papers 2006-7, pp. 18-20, http://chinaworld.cbs.dk/cdp/paper/ edmond.pdf. (accessed July 2006)

Hall, S. et al. (1978). Policing the crisis: mugging, the state, and law and order. London: Methuen.

Hall, S. (1982). The rediscovery of ideology: the return of the repressed. In Gurevitch, M. et al.: Culture, society, and the media. London: Methuen.

Hansen, A. (1993). The mass media and environmental issues. Leicester: Leicester University Press.

Kupusammy, B. (2006, March 2). Cartoon row blunts media edge. Asia Media Forum, http://www.asiamediaforum.org/node/405

Mann, M. (1986). The sources of social power, Vol.1, Cambridge UK: Cambridge University Press.

Nash, C. (2003). Freedom of the press in Australia. Democratic Audit of Australia, Australian National University http://democratic.audit.anu.edu.au/

Netto, A. (2005, September). Malaysia - making media monopolies. Asia Media Forum. http://www.asiamediaforum.org/node/288

Philippines Centre for Investigative Journalism, (1999). Lords of the press www.pcij.org/imag/PublicEye/lords4.html

Schlesinger, P. (1990). Rethinking the sociology of journalism: source strategies and the limits of media-centrism. In Ferguson, M. (Ed), Public communication: the new imperatives: future directions for media research. Thousand Oaks: Sage.

Tejapira, K. (2006). Toppling Thaksin. New Left Review, 39, May-June, pp. 5-37.

Tuchman, G. (1978). Making news: a study in the construction of reality. New York: Free Press.

Final results for the year ended December 31, 2004 (2005, April 1). The South China Morning Post. http://press.scmp.com/20050401.html 
Associate Professor Wendy Bacon is programme director in the Faculty of Humanities and Social Sciences at the University of Technology, Sydney. Associate Professor Chris Nash is director of the Australian Centre for Independent Journalism (UTS).

Anne Tran provided research assistance for this study. The authors thank her and the respondents at the Second International Conference on Environmental, Social and Cultural Sustainability in Hanoi, Vietnam, in January 2006, and the Public Right to Know Conference in Sydney in April 2006, where versions of this article were presented.

c.nash@uts.edu.au

w.bacon@uts.edu.au

\section{Pacific Journalism Review back copies}

Back copies of Pacific Journalism Review can be ordered from: University Bookshop Ltd (Auckland)

www.ubsbooks.co.nz

USP Book Centre www.uspbookcentre.com

PJR subscription details and order forms are online at: www.pjreview.info 